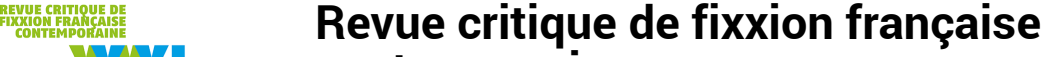 \\ WXI contemporaine
}

\section{Poetic Sabotage and the Control Society}

Christophe Hanna, Nathalie Quintane, Jean-Marie Gleize

\section{Nathalie Wourm}

\section{(2) OpenEdition}

\section{Journals}

Electronic version

URL: https://journals.openedition.org/fixxion/570

DOI: $10.4000 /$ fixxion.570

ISSN: 2295-9106

Publisher

Ghent University

Electronic reference

Nathalie Wourm, "Poetic Sabotage and the Control Society", Revue critique de fixxion française

contemporaine [Online], 20 | 2020, Online since 15 June 2020, connection on 17 May 2022. URL: http:// journals.openedition.org/fixxion/570 ; DOI: https://doi.org/10.4000/fixxion.570

This text was automatically generated on 17 May 2022

\section{cc) (1)}

Les contenus de la Revue critique de fixxion française contemporaine sont mis à disposition selon les termes de la licence Creative Commons Attribution - Pas d'Utilisation Commerciale - Pas de Modification 4.0 International. 


\title{
Poetic Sabotage and the Control Society
}

\author{
Christophe Hanna, Nathalie Quintane, Jean-Marie Gleize
}

Nathalie Wourm

1 Parallels can be drawn between Gilles Deleuze and Félix Guattari's concept of "minor literature" and the artistic practice of a number of contemporary French writers, whose works do not only represent the voicing of their political contentions, but also act as verbal objects designed to undermine the mainstream idea of what literature is and should be. In so doing, they aim to disrupt the political status quo, throwing "clogs in the machine" to bring about a form of literary sabotage ${ }^{1}$. Christophe Hanna, Nathalie Quintane, and Jean-Marie Gleize are three authors who share a number of theoretical ideas and political references and have been expressing their opposition to the system in this way. All are interested in the figure of Émile Pouget, the late $19^{\text {th }}$ and early $20^{\text {th }}$ centuries anarcho-syndicalist whose publications, including Le sabotage, Les lois scélérates de 1893-1894 and L'action directe, are fundamental to the anarchist movement in France. Hanna entitled his first theoretical monograph about the political potential of contemporary poetry, Poésie action directe, after Pouget's pamphlet ${ }^{2}$, and Gleize reproduced a version of L'action directe in his poetic review Nioques, a few years later ${ }^{3}$. Quintane offers a short introduction to Pouget in her 2010 book on the Tarnac affair in 2008, a group of young anti-capitalists living in the village of Tarnac were accused of terrorist activities and jailed, based for the most part on the publication of an anonymous anarchist text attributed to them ${ }^{4}$. Gleize also wrote a book on Tarnac ${ }^{5}$, an event which represents one of the more prominent and symbolic cases of the French state's recent assaults against freedom of speech, in particular that of the radical left. While this common attraction for the ideas of the historical figure of Pouget may seem anachronistic, it is relevant to the political situation in France today. As one of Quintane's later works attests, the general atmosphere is one of unrest and rebellion. In May 2018, fifty years after the Paris riots of 1968, she published a hefty book entitled Un oeil en moins, about the demonstrations of Spring 2016 against the "loi travail" (where a number of demonstrators lost an eye to rubber bullets), the Nuit Debout movement, the ZAD of Notre-Dame-des-Landes, and the treatment of migrants in the Calais "jungle". 
She refers to the 400-page publication as a "pavé", which can be understood in the two senses of a thick book and of a cobblestone to be used as a weapon against police violence (as in May 1968).

In a 1990 interview with Toni Negri, Deleuze calls for a "détournement de la parole" as a means of resistance against societies of control. The concept of détournement is associated with Guy Debord and the Situationist International, and their influence is one aspect of the similarity between Deleuze and Guattari's theory of literature and that of the three French writers. Another important point of commonality is the legacy of William Burroughs, and in particular the notions of control and - for Hanna in particular - of literature as virus. To what extent are Quintane, Hanna and Gleize criticising the society of control, while engaged in undermining it by diverting literature from its conservative (or "major") codes? And through which pathways do they come close to the Deleuzo-Guattarian vision of literature?

\section{The political context in early $21^{\text {st }}$-century France}

3 The tense political climate in France since the escalation of the terrorist threat in 2001, the clashes between modern-day anarchist groups and the authorities, as well as the violent control of social movements, are fundamental aspects of the three writers' radical poetics and explain its relevance. It is undeniable that France became a highly controlled society in the late $20^{\text {th }}$ and early $21^{\text {st }}$ centuries, when laws against terrorism, extended periods of state of emergency, and the anti-riot act, were deployed in response to events ranging from 9/11, through the Charlie Hebdo and Bataclan attacks in 2015, to the gilets jaunes rebellions of 2019. Critics have protested that these "precautionary measures" have also been used by successive governments to control society at large and repress dissent. In June 2009, a petition was launched by a group of intellectuals including Giorgio Agamben, in response to the recent Tarnac events, calling for the abrogation of the antiterrorist laws which have accumulated in France since 1986. The petition denounced a legal system that allows for suspects to be arrested on the basis of the undefined notion of "acte préparatoire". It also condemned "un système pénal d'exception qui renoue avec les lois scélérates" (the lois scélérates of 1893 and 1894 restricted freedom of the press and led to a series of controversial arrests and other repressive measures, following a wave of anarchist attacks) ${ }^{7}$. The petition also criticised antiterrorism for being "désormais une technique de gouvernement, un moyen de contrôle des populations"8. This text was signed by such prominent philosophers as Alain Badiou, Étienne Balibar, Daniel Bensaïd, Jacques Rancière, and Slavoj Žižek. It was also signed by Gleize who published his book, Tarnac, un acte préparatoire, two years later. In it, he uses cut-ups of the petition to reiterate his opposition to the arrests9.

Gleize and Quintane bring to their poetic practice this very critique of the current regime. Both experienced the Tarnac affair as a catalyst for a marked political turn in their writing. Gleize, who grew up in Tarnac - a village with a long communist history explains that he felt compelled to write on the "revolutionary question" in the works that followed the 2008 arrests $^{10}$. In Tomates, her book on Tarnac, Quintane describes how the arrests coincided with her reading of Auguste Blanqui, the $19^{\text {th }}$-century revolutionary socialist, who spent over three decades in prison and inspired later anarcho-syndicalism ${ }^{11}$. Quintane suggests that the coupling of the Tarnac events with 
Blanqui's texts had a powerful effect on her ${ }^{12}$. Tomates produces a mise-en-abyme, in that the narrative relates the gradual process by which Quintane came to the idea of writing a narrative on Tarnac. As the events unfolded and as the incarceration of Julien Coupat, which lasted over six months, appeared more and more unjust and unjustified (the police regarded him as the leader of the "anarchist" group and as the main author of the revolutionary pamphlet L'insurrection qui vient, published in 2007), she found the need to react increasingly pressing. Inspired by Pouget's description of the "workerpotato", or passive worker, who stirs from inertia into organised action, she decided to write the book ${ }^{13}$. In one of her essays, Quintane indicates that she subsequently came to the conclusion that it was necessary to write explicitly about politics in order to be heard ${ }^{14}$. While few journalists are drawn to literature, she added in an interview, books like Tomates can be noticed because journalists are interested in current affairs, and this inevitably gives them a glimpse of a type of literature that is not mainstream ${ }^{15}$. Since Tarnac, then, both Gleize and Quintane have been producing political texts, because, like Hanna, they believe that literature can be an efficient means of struggle. In that sense, they are participating in a long philosophical and literary tradition, but their approach is particular to their own political, philosophical, and literary backgrounds.

5 In 2018, ten years after the original arrests, the Tarnac group was acquitted of sabotage. The philosophers' petition now belongs to the archives. And yet, its content is still as valid now as it was then. In her 2019 book, Répression : L'État face aux contestations politiques, political scientist Vanessa Codaccioni argues that there has been an increase in state repression in recent years, and that there is a conflation of radical activism and terrorism. She cites the arrests, trials and incarcerations, the surveillance, and the mutilations and deaths through police violence ${ }^{16}$. In March 2019, the United Nations asked France for an enquiry into its excessive use of force during the gilet jaunes protests, further revealing the extent of the unease surrounding current modes of control by the government ${ }^{17}$. Again in 2019, in a book entitled Ennemis d'État: Les lois scélérates, des anarchistes aux terroristes, defence lawyer Raphaël Kempf writes about a system of censorship that is at play nowadays as it was under the lois scélérates. He suggests that the fight against terrorism is used as a pretext to systematically incarcerate and censor anyone expressing anarchistic opinions ${ }^{18}$. Kempf adds that both the old and new laws "visent très clairement ce qui est censé précéder le passage à l'acte : à savoir l'idée, l'écrit ou la parole, et bien évidemment celui qui la porte"19. The notion that those who question the social and political order are immediately criminalised is also put forward by Codaccioni ${ }^{20}$. In this context, it is easy to understand why Quintane claims, in Tomates, that the only really interesting books are those that the police reads, in addition to why she refers twice to Julien Coupat as "un homme jeune à idées" ${ }^{2}$. But this context also explains the more recent publications by Quintane and Gleize.

Quintane discusses the limits of the word "fascism" and its application to present-day France in Tomates, where she argues that fascism does not only refer to clear-cut dictatorial regimes, but that it can also insidiously appear anywhere in the form of relics from the past, and in a more uncertain way ${ }^{22}$. Gabriel Proulx analyses in detail the theme of fascism in the book, the significance of the extended gardening metaphor, and of symbols such as that of the state ban on homemade liquid manure ${ }^{23}$. In Un oeil en moins, Quintane uses a similar rhetorical method as in Tomates, starting with the notion that the word "fascism" should not be used "pour un oui pour un non" ${ }^{24}$. With a 
measure of irony, she claims that it would be rash to describe as fascist "des régimes de gouvernance à tendance dirigiste où la surveillance, le contrôle, la contrainte, n'étaient pas francs mais diffus, insidieux, implicites" ${ }^{25}$. Quintane makes further use of comic effect to render her end point all the graver. Playing on the absurdity of a series of Socratic questions comparing present-day France to the past, she gradually comes to the serious argument that while a strict definition of historical fascisms cannot be replicated, there are feelings of déjà-vu, aspects that return, in the ever-changing present. She then lists a number of methods recently used by the French state to quell dissent: "l'assignation à résidence, les listes, les fiches, l'intimidation, la bastonnade des récalcitrants, la disproportion des condamnations, les termes de terreur et de terrorisme, les camps..." ${ }^{26}$. More recently, in Les enfants vont bien, Quintane eschews her customary humorous style altogether to produce a piece of work that is both protest at the violence of the way France treats its refugees and warning regarding the relative indifference of the population ${ }^{27}$. Unlike her previous book, this is not a narrative, but a type of collage, with fragments being positioned on each page according to the attitude towards refugees that they betray. Those of cynical politicians figure right at the top in large characters ("Ce qui monte, c'est l'exaspération des braves gens, de ces gens bien élevés qui n'en peuvent plus" ${ }^{28}$ ), and are contrasted with those of humanitarian aid workers, in tiny script at the bottom ("Statu quo pour la plupart des familles, si ce n'est qu'elles ont toutes du mal à se procurer à manger!" ${ }^{29}$ ). Meanwhile, the neutral legal, administrative and press cuttings appear in the middle ("où le taux de mortalité reste relativement constant, autour de 1 pour $40^{\prime 30}$ ). Quintane decries the fate of those who are "[c]ontrôlés, ayant à peine de quoi vivre, et avertis qu'ils n'auront rien s'ils pensent à protester" 31 .

7 Gleize, like Quintane, writes against contemporary fascism and the treatment of those who appear to threaten the bourgeois order. In Trouver ici, published in 2018, he describes a scene that follows the violent evacuation and destruction of some refugee camps. Reflecting on the devastation, the abandoned dolls amidst the smell of pepper spray, he warns about the fascisation of bourgeois democracy: "La dictature de la bourgeoisie peut s'exercer sous deux formes / Sous deux formes dont l'une est la démocratie bourgeoise / Dont l'autre est le fascisme" ${ }^{32}$. From the publication of Tarnac, un acte préparatoire onwards, Gleize develops the idea of the shack, or cabane, as a means of resistance against the oppressions of the capitalist order. The concept of shack building, he explains, which is central to the 2015 volume Le livre des cabanes, is reminiscent of the practice of nomads, who build ephemeral and autonomous shelters. These shacks exist in France in the form of refugee camps such as in Calais, of the Zones à Défendre (or ZAD) such as in Sivens or Notre-Dame-des-Landes, and in communities such as Tarnac. Gleize also uses the shack image less literally for other modes of resistance, such as "les structures éditoriales autonomes et parallèles qui accueillent les pratiques d'écriture mineures ou marginales, comme la poésie par exemple. Ces cabanes sont des abris nomades" ${ }^{33}$. The similarity between Gleize's notion of nomadism, and Deleuze and Guattari's nomadology, should be noted. In "Traité de nomadologie : la machine de guerre" ${ }^{34}$, Deleuze and Guattari regard the nomad as a "war machine" against the state apparatus, as resistance against the state's control of space and movement. The state is the agency that distributes "closed space", that draws borders, and creates laws or the polis, which the nomad opposes. And, they argue, "chaque fois qu'il y a opération contre l'État, indiscipline, émeute, guérilla ou révolution comme acte, on dirait qu'une machine de guerre ressuscite, qu'un nouveau potentiel 
nomadique apparait, avec reconstitution d'un espace lisse ou d'une manière d'être dans l'espace comme s'il était lisse" 35 . Gleize mentions the ephemeral constructions as a rejection of "une certaine organisation des choses et de l'espace qui nous est donnée comme inéluctable". He also describes his writing as conceived in terms of this nomadic existence: "Utiliser pour écrire les accidents du sol implique que ce déplacement permanent tienne le plus grand compte du terrain, des obstacles" ${ }^{36}$. In the same way, Deleuze and Guattari explain the trajectory of the nomad as determined by the local topology and its accidental factors: "Le désert de sable ne comporte pas seulement des oasis, qui sont comme des points fixes, mais des végétations rhizomatiques, temporaires et mobiles en fonction de pluies locales, et qui déterminent des changements d'orientation de parcours" ${ }^{37}$. Gleize views his writing as a mode of resistance, of struggle against the state apparatus, as a form of literary activism.

\section{Literary activism and the control society}

8 The context in which Quintane and Gleize have been expressing political dissent through their poetic practice is one of engagement with the recent history of French left-wing radicalism combined with what could be referred to as an unmediated literary activism. What they propose is to act directly against the system by interfering with the form and content of the dominant rhetoric, by deliberately distorting or vandalising it. Hanna theorises this type of political writing in Poésie action directe as "un processus de sabotage des systèmes symboliques d'une société [...] un art du détournement et de la guérilla urbaine" ${ }^{38}$. This discourse represents a paradigmatic shift from the traditional concept of littérature engagée in the Sartrean sense, to a more hands-on position ${ }^{39}$. Here, the poetic object itself is used as an instrument in the struggle against the regime, infiltrating and modifying established codes of communication. Gleize speaks of appropriating "la langue de l'ennemi pour mieux s'insinuer dans ses réseaux de communication, pervertir ou détourner ses messages, ses systèmes de figuration" ${ }^{40}$. According to him, the difference between the aims of contemporary political poets and that of the 1960s to 1980s avant-gardes is that the avant-gardes were interested in subverting language itself, in transgressing linguistic codes, and in so doing, were inevitably difficult to read. But the goal of the new generation is to work with text within the system. The idea is not to be unreadable anymore, but to be as easily accessible as possible in order to seamlessly sneak into society's communication networks ${ }^{41}$. While both Hanna and Gleize use Situationist vocabulary as a springboard, their outlook goes beyond the objectives of the Situationist International. Reflecting on Debord's legacy, Hanna considers that, in philosophy nowadays, "[l]es concepts de situation et de spectacle ont été repensés à la lumière des philosophies analytique et pragmatique" ${ }^{42}$. Hanna's interest in American pragmatism and neo-pragmatism is fundamental to his vision of a politically meaningful contemporary writing ethics. Both his theoretical books offer elaborate discussions informed by John Dewey, C. S. Peirce, and Richard Rorty ${ }^{43}$. For this reason, Jean-François Hamel places Hanna's politics of literature at the crossroads of situationism and pragmatism ${ }^{44}$. What this means in practice is that Hanna advocates a poetic practice that can have political and social impact through a process of interference with other "symbolic systems" ${ }^{45}$. In Nos dispositifs poétiques, he presents his vision of what could be regarded as a form of literary camouflage, in that text blends in 
with the social context that it aims to act upon ${ }^{46}$. In that sense, it is not readily identifiable as literature. Rather, it is a transformative poetic device ${ }^{47}$.

One example of interference with other symbolic systems and of literary camouflage is Quintane's Les enfants vont bien. The collage of fragments of text spoken or written by politicians, law-makers, administrators, journalists, and aid-workers creates an artefact that does not look like literature - what Pierre Alferi and Olivier Cadiot would call an "unidentified verbal object" 48 . Here, the language of the state apparatus is being diverted and infiltrated. First, it is cut up into pieces, and organised according to its degree of cynicism. Then, the organised fragments are published in the form of a literary book by P.O.L. In that sense this language undergoes a process of détournement. At the same time, the poetic infiltrates state discourse in that the manipulation of fragments creates the conditions for the expression of political dissent - both Quintane's and that of the readers. This is because the act of reading will inevitably produce an analysis, as the reader reflects on the reason a fragment was chosen. In her introduction, Quintane indicates that the book is not a narrative, but that it follows a loose chronology which the reader can easily follow, starting with the opening of a reception centre for refugees in provincial France ${ }^{49}$. The reader is an active participant in the creation of meaning and the piece of work is therefore transformative, acting on the social context, undermining the dominant discourse. As Justine Huppe writes regarding Quintane's books since Tomates, "Ses textes trouvent ainsi leur parfaite description dans celle que Christophe Hanna donne des 'dispositifs poétiques' [...] Cet intérêt pour l'efficacité du texte est explicite chez Quintane”"50.

10 Another aspect of Quintane's art of détournement and infiltration is to be found in the style of her prose. Huppe offers a detailed analysis of the style that Quintane adopts in Tomates and Un oeil en moins to undermine bourgeois idiom. Quintane is highly critical of the stilted, old-fashioned manner of speech which is usually associated with great French prose, and which is alien to $21^{\text {st-century readers. Huppe describes Quintane's }}$ choice of style as political: "[E]lle désencombre [...] sa langue de ses décorations stylistiques, qui sont autant de marqueurs sociaux"51. Quintane often relies on the reproduction in written form of everyday spoken language. In this way, she sabotages conservative literature by infiltrating its usual channels - the "literature" sections in bookshops and libraries - while offering a dehierarchisation of the literary activity. In Kafka : Pour une littérature mineure, Deleuze and Guattari describe language as a hierarchical system used for the transmission of orders, the exercise of power ${ }^{52}$. They put forward the idea that it is possible to resist a dominant or "major" language by subverting it, or making it "minor", principally through the medium of literature. In this sense, minor literature has revolutionary potential within a major tradition ${ }^{53}$. Deleuze and Guattari are not a direct influence on Quintane $e^{54}$, but she is part of a group of writers who have read the influential essay "La mécanique lyrique", published by Alferi and Cadiot in 1995, and which Hanna regards as a manifesto ${ }^{55}$. Cadiot is a Deleuzian $^{56}$, and Alferi considers that their essay is Deleuzo-Guattarian in the sense that "[n]ous étions tous les deux viscéralement du côté de la multiplicité et de l'horizontalité, au sens au moins de la déhiérarchisation, plutôt que du côté des systèmes de pensée hiérarchisés, exclusifs et autoritaires" ${ }^{27}$.

11 There are other parallels between the works of Quintane, Gleize, and Hanna, and the philosophy of Deleuze and Guattari. Of course, the history of writers who believe in the power of insurgent literature is long, and distinct from Deleuzo-Guattarian theories. In 
fact, Quintane once exclaimed that journalists and academics who argue that her work is radical clearly know little about literature ${ }^{58}$. Nevertheless, the similarities with some of the two philosophers' ideas are worth noting. In Poésie action directe, Hanna develops the images of computer viruses and of spin (as in propaganda) to illustrate the concept of poetic sabotage - a Pougetian direct action transposed to poetry ${ }^{59}$. The notion of the computer virus as a modern form of sabotage is one that Deleuze considers in his 1990 interview with Negri about control societies ${ }^{60}$. Deleuze sees the virus as a means of resistance against state control, which seems apt in that viruses are rhizomatic ${ }^{61}$. During a 1987 conference entitled “Qu'est-ce que l'acte de création?", Deleuze mentions Burroughs in relation to the concept of control, and links it to Michel Foucault's idea of disciplinary societies. Deleuze implies that Foucault, an admirer of Burroughs, believed that disciplinary societies were engaged in the process of becoming control societies ${ }^{62}$. While it may have been the case that Foucault was thinking in such terms, there is nothing in his works about this passage from disciplinary societies to control societies. Michael Hardt suggests that Deleuze is "articulating after Foucault's death an idea that he finds inarticulate or unarticulated in Foucault's work" ${ }^{63}$.

Reflecting on the concept of control and its limits in a 1975 essay, William Burroughs posits that "words are still the principal instruments of control. Suggestions are words. Persuasions are words. Orders are words" ${ }^{64}$. He then argues that "[m]odern control systems are predicated on universal literacy since they operate through the mass media" ${ }^{65}$. He suggests that, while it is possible to control a people by maintaining its illiteracy, it is also possible to achieve the same effect by "informing" it, by promoting its literacy in order to manipulate it ${ }^{66}$. Deleuze and Guattari's write in Mille plateaux that the rules of a given society are communicated through the rules of language ${ }^{67}$. Power is imprinted in the grammar which is taught in schools. Teachers impart "coordonnées sémiotiques"68 a type of mapping and signposting to navigate the world according to the structures set out by rulers: "L'unité élémentaire du langage - l'énoncé -, c'est le mot d'ordre [...] Une règle de grammaire est un marqueur de pouvoir, avant d'être un marqueur syntaxique [...] Le langage est une carte et non pas un calque" ${ }^{69}$. Therefore, Deleuze and Guattari argue, what passes for "information", as well as "communication" from the police or the state, are really injunctions to obey ${ }^{70}$. It is clear that these analyses by Burroughs and Deleuze and Guattari are close to that of the commentators on and opponents of the current regime in France. Agamben's petition was a protest against the state's use of antiterrorism as a technique to control the population. Kempf suggested that governments are keeping a close eye on "ideas", in spoken or written form, and on those who express them.

While it is true that the essay or manifesto "La mécanique lyrique" was DeleuzoGuattarian in some respects, it does not fully account for all the parallels that can be made with the two philosophers. However, common sources, for Hanna at least, are Foucault and Burroughs. In 2011, Hanna himself explained that although he was not particularly familiar with Deleuze and Guattari, he had arrived at the same questions through different thinkers: "Ce qui a été déterminant pour mes réflexions théoriques, la question de la subjectivation, c'était plutôt Foucault. Et en particulier tous ses travaux sur les dispositifs de contrôle, sur le pouvoir, la conception qu'il se fait de la constitution d'une société" 71 . But Hanna is also interested in Burroughs, whom he cites in Poésie action directe, as the writer who popularised the idea of literature as electronic virus $^{72}$. Hanna offers an extensive theory of poetry as virus, as "guérilla virale" 73 , referencing the Electronic Revolution, which was first published by Burroughs in 1970. In 
it, Burroughs suggests that words are like viruses that have the ability to control the minds of people. He mentions ways in which the "word virus" can be manipulated to achieve this power: "The underground press serves as the only effective counter to a growing power and more sophisticated technique used by establishment mass media to falsify, misrepresent, misquote". The answer is to turn the language weapon against itself through the use of cut up techniques ${ }^{74}$. Hanna's virus poetry is similarly deployed against common mediums, such as newspapers, journals, trendy websites, or educational CD-ROMs. The idea is for poetry to infiltrate them. However, Hanna explains, it is not simply a matter of showcasing poems using new technologies ${ }^{75}$. Rather, virus poetry corresponds to a sort of hijacking of the medium itself. This is how he operates in works such as Les Berthier : Portraits statistiques (2012) and Argent (2018) which are real statistical surveys that have specific political implications. In his study of Les Berthier, Hamel quotes Pierre Bourdieu who considers that, to understand the power of the state, it is necessary to take "administrative prose" seriously, and that statistics are a technique of government ${ }^{76}$. In this sense, Hanna's statistical surveys are similar to Quintane's cuttings in Les enfants vont bien. They manipulate the language of the state and divert it, giving the reader the tools to analyse it in the different context of a literary publication. In the case of Les Berthier, which was published under the pseudonym of "La Rédaction" because Hanna considers his role to have been merely editorial, rather than authorial, the idea was largely to undermine the second electoral campaign of Nicolas Sarkozy, in 2012. Secondarily, once the election over, it was meant to act as a weapon against "cet ensemble de pratiques et de croyances qu'on nomme le sarkozysme"77. Hanna sees Burroughs' virus metaphor as a variant of the idea of the book as a bomb alongside, for instance, Lautréamont's shovels of headlice ${ }^{78}$.

\section{Conclusion}

When thinking about radicalism, one question that imposes itself is whether or not the radical party is really the one that is critical of the control society. In a 2018 interview about the acquittal of the Tarnac group in a mainstream magazine, Codaccioni argues that the age-old confusion between radical activism and terrorism has been significantly more marked since 2000 . She believes that the emergence of "alternative globalisation" groups and of the black bloc phenomenon have contributed to a reinforcement of this conflation. She also considers that there is a radicalisation of antiterrorism in the aftermath of $9 / 11$, as well as a radicalisation of the repression against social movements ${ }^{79}$. Her use of the word "radicalisation" to refer to the evolution of governmental repression in recent years is meaningful. Is it radical to protest against the state machine's maiming of demonstrators, or its violent destruction of refugee camps? In the alternative online journal Lundimatin for which she is a regular contributor, Quintane ironises:

D'accord, y a 1 morte, 24 éborgnés, une demi-douzaine de mains arrachées et 280 blessures à la tête chez les manifestants, mais justement on peut l'écrire et je l'écris : dans un état autoritaire, je ne pourrais pas l'écrire ; c'est donc la preuve que je suis dans un état de droit, moi, en ce qui me concerne..$^{80}$

15 Through their rhetoric, governments insidiously attempt to normalise and justify the use of violence. Answering on the radio recent criticisms that France has now become a dictatorship, French president Emmanuel Macron exclaimed: "Mais allez en dictature! [...] Si la France, c'est ça, essayez la dictature et vous verrez!”. He described the critics 
as guilty of spreading seditious ideas. Macron also accused all those who do not speak up against these attacks of being "accomplices" in the weakening of French democracy and the republic ${ }^{81}$. His use of language is interesting in that it implies that there is a form of treason against the higher values of freedom and equality, when these are the very values that people are fighting for.

Quintane and Gleize are both interested in the possibility of a communism ${ }^{82}$, of creating a communism that has yet to be defined. "Communism", argues Gleize, "is a word with an open meaning, one that must be reinvented" ${ }_{83}$. In that sense, he is close to Alain Badiou who, in L'hypothèse communiste, criticises the idea that past failures of communist regimes are a fatality proving that capitalism is the only possible and the best system. Badiou considers that centuries of capitalism have proved far more destructive than the few years of bloody and costly communist experiments to which it is compared ${ }^{84}$. Gleize is also more optimistic than Deleuze in his response to Negri's questions:

Vous demandez si les sociétés de contrôle ou de communication ne susciteront pas des formes de résistance capables de redonner des chances à un communisme conçu comme « organisation transversale d'individus libres ». Je ne sais pas, peutêtre. ${ }^{85}$

For Gleize, in Le livre des cabanes, communism is the possibility of intensifying joy, and is neither a fantasy nor a utopia ${ }^{86}$.

\section{ENDNOTES}

1. See Gilles Deleuze's 1990 interview with Toni Negri, entitled "Contrôle et devenir", in Pourparlers 1972-1990, Paris, Minuit, 2003, p. 237: “ce qu'on appelait au XIX' siècle 'sabotage' (le sabot dans la machine)". NB: This etymology is not recorded in Le Trésor de la langue Française informatisé (<http://www.atilf.fr/tlfi>) and may be inaccurate.

2. Christophe Hanna, Poésie action directe, Romainville, Al Dante, 2003.

3. Revue Nioques, $\mathrm{n}^{\circ}$ 7-8, May 2010.

4. Nathalie Quintane, Tomates, Paris, P.O.L, 2010, p. 80-81. The pamphlet, entitled L'insurrection qui vient (after Agamben's La comunità che viene), was published anonymously by "Le Comité Invisible".

5. Ibid., and Jean-Marie Gleize, Tarnac, un acte préparatoire, Paris, Seuil, 2011.

6. Nathalie Quintane, Un oeil en moins, Paris, P.O.L, 2018.

7. See Francis de Pressensé, a lawyer, and Émile Pouget, Les lois scélérates de 1893-1894, Paris, La Revue Blanche, 1899, available online at <https://gallica.bnf.fr/ark:/12148/bpt6k836767.pdf>. For an explanation of the 1893 and 1894 laws, see Frédéric Gras, "Des 'lois scélérates' aux premières applications par les tribunaux du délit d'apologie de terrorisme”, Légicom, 2016, vol. 2, n 57, p. 59-61.

8. The text of the petition is available on the "Ligue des droits de l'Homme" website at <https:// www.ldh-france.org/Petition-Pour-en-finir-avec-les/>.

9. Jean-Marie Gleize, Tarnac, un acte préparatoire, p. 15-16. 
10. See Emmanuèle Jawad's interview of Gleize on the Diacritik website: <https://diacritik.com/ 2018/05/02/le-texte-est-hante-entretien-avec-jean-marie-gleize-trouver-ici/>.

11. Nathalie Quintane, Tomates, op. cit., p. 9.

12. Ibid., p. 10.

13. Ibid., p. 80-89.

14. Nathalie Quintane, Les années 10, Paris, La Fabrique, 2014, p. 197.

15. Nathalie Wourm, Poètes français du $21^{e}$ siècle : entretiens, Leiden, Brill, 2017, p. 85.

16. Vanessa Codaccioni, Répression: L'État face aux contestations politiques, Paris, Textuel, 2019, p. 7-8.

17. See the report in Le Monde of 6 March 2019 available at <https://www.lemonde.fr/societe/ article/2019/03/06/l-onu-demande-a-la-france-une-enquete-sur-l-usage-excessif-de-la-forcependant-les-manifestations-de-gilets-jaunes_5432222_3224.html>.

18. Raphaël Kempf, Ennemis d'État: Les lois scélérates, des anarchistes aux terroristes, Paris, La Fabrique, 2019, p. 8 .

19. Ibid., p. 16.

20. Vanessa Codaccioni, Répression: L'État face aux contestations politiques, op. cit., p. 8.

21. Nathalie Quintane, Tomates, op. cit., p. 65, 18, 63.

22. Ibid., p. 35-37.

23. Gabriel Proulx, "Fluidité générique dans Tomates de Nathalie Quintane : poésie, roman, essai littéraire", Études littéraires, vol. 46, n³, 2015, p. 157-168.

24. Nathalie Quintane, Tomates, op. cit., p. 35 and Un oeil en moins, op. cit., p. 132.

25. Un oeil en moins, op. cit., p. 132.

26. Ibid. p. 134.

27. Nathalie Quintane, Les enfants vont bien, Paris, P.O.L, 2019, p. 7-11.

28. Ibid., p. 128.

29. Ibid., p. 103.

30. Ibid., p. 129.

31. Ibid., p. 10.

32. Jean-Marie Gleize, Trouver ici, Paris, Seuil, 2018, p. 35-36.

33. Jean-Marie Gleize, "J'utilise pour écrire les accidents du sol", Contemporary French and Francophone Studies, vol. 21, n²4, 2017, p. 383-385.

34. Gilles Deleuze, Félix Guattari, Mille plateaux, Paris, Minuit, 1980, p. 434-527.

35. Ibid., p. 472, 480.

36. Jean-Marie Gleize, “J’utilise pour écrire les accidents du sol”, op. cit., p. 386.

37. Ibid., p. 474.

38. Christophe Hanna, Poésie action directe, op. cit., p. 25-26.

39. This shift was initiated by the avant-gardes of 1960-1980 through the concept of "langagement", as Gleize explains in "Opacité critique" in "Toi aussi, tu as des armes" : poésie \& politique, Paris, La Fabrique, 2011, p. 38-39.

40. Ibid., p. 39.

41. Ibid., p. 38-39.

42. See Raphaëlle Rérolle, “À chacun son Debord”, Le Monde, 21 March 2013.

43. See also Hanna's explanation in Nathalie Wourm, op. cit., p. 72 : "Les auteurs qui m'ont aidé à me détacher de formes d'écritures qui ne m'étaient pas secourables, étaient les néo-pragmatistes américains, qui sont influencés par Wittgenstein et les pragmatistes vieux, comme James ou Dewey. C'était des personnes comme Richard Rorty, essentiellement, qui essayaient de reconcevoir la question de la démocratie, par certains aspects. Dewey aussi, pour la question du problème public, la question d'expérience." 
44. Jean-François Hamel, "Détourner la science de l'État. Politique de la littérature et dispositif poétique dans 'Les Berthier. Portraits statistiques' de la Rédaction”, Cahiers de l'Association internationale des études françaises, vol. 67, May 2015, p. 58-60.

45. Christophe Hanna, Poésie action directe, op. cit., p. 9, 26.

46. Christophe Hanna, Nos dispositifs poétiques, Paris, Questions Théoriques, 2010, p. 6-7.

47. Ibid., p. 217.

48. Pierre Alferi, Olivier Cadiot, Revue de littérature générale, Paris, P.O.L, 1995, p. 6.

49. Nathalie Quintane, Les enfants vont bien, op. cit., p. 9.

50. Justine Huppe, "L'insurrection qui vient par la forme", COnTEXTES, n² 22, 2019, url : https:// journals.openedition.org/contextes/6975.

51. Ibid.

52. Gilles Deleuze, Félix Guattari, Kafka : Pour une littérature mineure, Paris, Minuit, 1975, p. 43

53. Ibid., p. 33.

54. "[J]e ne suis ni deleuzienne ni derridienne, je suis nervalienne", Nathalie Wourm, op. cit., p. 83.

55. Christophe Hanna, Nos dispositifs poétiques, op. cit., p. 1.

56. Nathalie Wourm, op. cit., p. 34-35.

57. Ibid., p. 43.

58. Ibid., p. 84.

59. Christophe Hanna, Poésie action directe, op. cit., p. 19-32.

60. Gilles Deleuze, op. cit., p. 237.

61. In Mille plateaux, Deleuze and Guattari speak of biological viruses as rhizomatic: "Nous évoluons et nous mourons de nos grippes polymorphes et rhizomatiques", Gilles Deleuze, Félix Guattari, Mille plateaux, op. cit., p. 18.

62. The relevant extract of the conference given as part of the "Mardis de la Fondation Femis" and dated 17 March 1987, is available on video at <https://www.youtube.com/watch? v=4ybvyj_Pk7M>. The transcript is available at <https://www.webdeleuze.com/textes/134>.

63. Michael Hardt, “The Global Society of Control”, Discourse, Fall 1998, vol. 20, n³, p. 139.

64. William Burroughs, The Adding Machine: Selected Essays, New York, Arcade Publishing, 1993, p. 117.

65. Ibid., p. 118.

66. Ibid.

67. Gilles Deleuze, Félix Guattari, Mille plateaux, op. cit., p. 95-139.

68. Ibid., p. 95.

69. Ibid., p. 95-98.

70. Ibid., p. 96.

71. Nathalie Wourm, op. cit., p. 72.

72. Christophe Hanna, Poésie action directe, op. cit., p. 21.

73. Ibid., p. 24.

74. William Burroughs, The Electronic Revolution, ubu classics, p. 14, url : <http://www.ubu.com/ historical/burroughs/>.

75. Christophe Hanna, Poésie action directe, op. cit., p. 26.

76. Jean-François Hamel, op. cit., p. 68.

77. Christophe Hanna, "Pourquoi nous avons rédigé Les Berthier de cette façon", Écrire l'histoire, $\mathrm{n}^{\circ}$ 12, 2013, url : <http://journals.openedition.org/elh/350>.

78. Christophe Hanna, Nos dispositifs poétiques, op. cit., p. 218, and Poésie action directe, op. cit., p. 21.

79. Vanessa Codaccioni, "Procès Tarnac: comment expliquer un tel fiasco?" in Les inrockuptibles, 16 April 2018, url : <https://www.lesinrocks.com/2018/04/16/actualite/societe/proces-tarnaccette-relaxe-est-un-acte-de-resistance-et-de-revalorisation-de-lautorite-judiciaire>. 
80. Nathalie Quintane, "Si la littérature est une niche", 13 May 2019, url : <https://lundi.am/Sila-litterature-est-une-niche>.

81. Macron's comments can be found in Le Monde of 24 January 2020.

82. See in particular Nathalie Quintane, "Possible" in Pour un communisme, Saint Julien Molin Molette, Jean-Pierre Huguet Éditeur, 2009, p. 23-26. Gleize's references to communism are widespread throughout his literary and critical works, as well as his many interviews.

83. Jean-Marie Gleize in "Jean-Marie Gleize by Noura Wedell : An invitation to disorder: poetry, insurrection, and concrete utopia", Bomb Magazine, 22 September 2014, url : <https:// bombmagazine.org/articles/jean-marie-gleize/>.

84. Alain Badiou, L'hypothèse communiste, Paris, Nouvelles Éditions Lignes, 2009.

85. Gilles Deleuze, op. cit., p. 237.

86. Jean-Marie Gleize, Le livre des cabanes, Paris, Seuil, 2015, p. 41.

\section{ABSTRACTS}

Cette étude du rapport entre théorie et politique dans les pratiques poétiques de Christophe Hanna, Nathalie Quintane et Jean-Marie Gleize, propose d'abord un contexte historique, culturel, littéraire et philosophique de leurs travaux les plus récents. L'article considère l'intérêt de ces trois auteurs pour le socialisme révolutionnaire et l'anarcho-syndicalisme du XIXème siècle, et la manière dont les figures d'Auguste Blanqui et d'Émile Pouget informent leur appréhension du début du XXIèmesiècle en France. L'agitation sociale et la répression des gouvernements successifs, le symbole que représente l'affaire de Tarnac, et le traitement des zadistes, des réfugiés, et de ceux qui bousculent le statu quo, sont pris en considération. D'autre part, cet article suggère des pistes d'interprétation dans les philosophies de Michel Foucault et de Gilles Deleuze et Félix Guattari, ainsi que dans l'œuvre de William Burroughs. L'étude montre qu'une résistance littéraire à la « société de contrôle » est possible.

\section{INDEX}

Mots-clés: contrôle, politique, poétique, Tarnac, ZAD (zone à défendre)

\section{AUTHORS}

\section{NATHALIE WOURM}

Birbeck, University of London 